\title{
Study on the Development Model of College English Major
}

\author{
Hongbin Li
}

\author{
Jilin Business and Technology College \\ 51051519@qq.com
}

Keywords: College English Major, Development Model, Teachers Cooperation

\begin{abstract}
The professional development of college English teachers has become an important aspect of teacher education development. The professional development of college English teachers should be based on the practice of college English teaching, pay attention to the improvement of professional practice activities, so that teachers themselves become teachers educators, thus changing the past only rely on degree and teacher training to promote the professional development of college English teachers. This study focuses on the way to realize the professional development of college English teachers, namely teachers' self-exploration, teachers' cooperative development and teachers' network learning, communication and cooperation.
\end{abstract}

\section{Introduction}

Teachers 'professional development has two meanings: from the irreplaceability of teachers' occupations, teachers are a kind of specialized occupations. From the perspective of professional development of teachers, pre-service teacher training should be combined with in-service teacher training as a complete and continuous development process. For the concept of professional development of teachers, many scholars at home and abroad have given a discussion. Comprehensive academic point of view, that the professional development of teachers is the teacher professional knowledge and professional skills self-growth process, is the internal professional structure constantly updated, evolving and rich process. In this process both the teachers themselves need to continue their efforts, but also need to give appropriate support from the outside world. The purpose of professional development is to improve the quality of teachers, to adapt to the needs of society and practice, advancing with the times, improve the ability of lifelong learning, improve teaching effectiveness and improve teaching quality. Teachers professional development is the individual teacher, the inherent professional improvement, is the teacher's professional growth or teacher's internal professional structure of the constantly updated, evolving and rich process. Teachers' professional knowledge is one of the core contents of teacher professional development and teacher training. On this basis, the main problem to be solved in this research is how to improve the teachers 'understanding of educational phenomena and teaching behaviors and increase the tacit knowledge of teachers' education and teaching, and finally promote the professional development of teachers.

\section{The Connotation and Value Orientation of Major Development of College English}

Professional (profession) is with the "ordinary occupation (vocation)" relative to the. "Ordinary occupation" contains less mental labor, its essence is the repetition of the basic operational behavior. Professional refers to "specialized occupation", it refers to a group of people through specialized training, with specialized knowledge and technology, in accordance with certain professional standards to provide specialized services to promote social progress and access to the corresponding social status and remuneration. For judging professional standards, Carr Saunders (1993) argues that professions are formal occupations. In order to engage in this profession, long-term pre-job training is necessary, and the characteristics of intelligence, including knowledge and some expansion of knowledge, which is different from the simple skills. Professional is mainly to serve as a motive, rather than simply make a living tool. Chinese scholars believe that the professional has three essential characteristics: indispensable social function; perfect professional theory and mature 
professional skills; a high degree of professional autonomy and authoritative professional organization.

From the "professional" to "professional", the need for a development process, that is, "professional specialization." Hoyle is the first to put forward the "professional" concept of the scholars. According to his view, specialization refers to the general career after a period of development, to meet professional standards of this process. Specialization involves two simultaneous and independent processes, one for the improvement of position, the development of the profession, the improvement and improvement of the professional knowledge and technology. There are scholars believe that specialization refers to the general professional groups gradually meet the professional standards, access to professional status of the process; In addition, it also means that the professional group of professional nature and status in what circumstances and level. In general, there are two dimensions of specialization: the improvement of status and the improvement of practice.

\section{Investigation on the Current Situation of College English Major Development}

This study was conducted in September 2010 to December in an ordinary comprehensive university in northern China. The school was included in the year in 2003, one of the 180 college English teaching reform pilot schools, after several years of pilot class experiment, in 2006, this two students in the full implementation of computer and classroom-based teaching model, and With remarkable results. In 2007, the school was named the Ministry of Education College English teaching reform demonstration institutions, college English courses were rated as national excellent courses. In 2010, by the college English backbone teachers composed of "college English new model teaching team" was named the national teaching team. In the context of the current college English teaching reform vigorous, the colleges and universities have experimental teaching new model in the background, choose the school of college English teachers as a survey object, with a typical and representative. The school is one of the two major English college English teachers a total of 67 people, mainly young and middle-aged teachers. Among them, six of them are college teachers who have been under 3 years of age, and the rest of the teachers are taught in college English for more than five years. 49 teachers have a master's degree, accounting for 73\%, of which two teachers are studying for a doctorate. 3 professors, 25 associate professors, 28 lecturers, 11 teaching assistants, associate professors and above titles accounted for about $42 \%$ of teachers. The author first conducted a questionnaire survey of all college English teachers. In order to gain a better understanding of the status quo of its professional development, to obtain more information, the survey to take "purpose of sampling", according to the survey results selected 7 people as qualitative research object, accounting for about $10 \%$ of all teachers. The questionnaire survey shows that the seven teachers are concerned and familiar with the reform of college English teaching, self - development is good, in the teaching practice has a certain sense of reflection, can actively cooperate with the smooth progress of this study.

Quantitative study: The quantitative research tool of this study is "questionnaire survey of college English teachers' professional development under the new teaching mode". The questionnaire is widely read on the basis of the relevant literature, after repeated demonstration and modification design, divided into three parts, 40 questions. The purpose of this study is to investigate the work, life and research environment of college English teachers in the teaching line, to understand their teaching ideas and classroom behavior, and to provide a solid foundation for the study of college English teacher education and development. (2) qualitative research on the selected seven typical samples for classroom observation, interviews, etc., the use of multiple qualitative analysis methods to increase the understanding of teaching processes and teaching phenomena, to achieve the dynamic development of teachers dynamic research, to improve the research Reliability. Quantitative research and qualitative research can be used in combination. In this study, the quantitative data provided the basis for the scope and level of the stereotyped research. The qualitative research paid more attention to the dynamic development of individual English teachers. Through classroom observation and interview, it helped to analyze the quantitative data better and 
more deeply Come to a scientific, real conclusion.

Table 1 Questionnaire Part 1 Statistics

\begin{tabular}{|l|l|l|l|}
\hline & Mean & Standard deviation & Number of samples \\
\hline Teaching reform & 4.3528 & 0.61593 & 67 \\
\hline $\begin{array}{l}\text { Personal attitudes } \\
\text { and abilities }\end{array}$ & 4.4857 & 0.56835 & 67 \\
\hline Teaching practice & 4.3825 & 0.65724 & 67 \\
\hline
\end{tabular}

Teachers in the teaching process should have a sense of reflection, to their own teaching methods, teaching methods, teaching organization and management, as well as students' classroom performance, learning effects and so on. Reflection can enable teachers to carry out the next step of the teaching action by thoughtful and purposeful. Teaching reflection is the only way for excellent teachers to grow. In a variety of lectures, lectures, open classes and other activities, college English teachers can get experts, colleagues evaluation and feedback, and that this way is very effective. However, in the specific operation, many teachers because of their own theoretical knowledge or ability is limited, or because of work, life pressure can not sum up these comments and improve. Therefore, college English teachers should not only establish a positive reflection and reflection attitude, but also pay attention to cultivate their ability to reflect, timely summary, and strive to improve the next step in teaching.

In China, the concept of exam-oriented education has a long history, or even deep-rooted. Although most teachers agree with the new ideas of listening, speaking, self-learning and teacher-student interaction advocated by "curriculum requirements", it is always difficult to get rid of the shackles of exam-oriented education in teaching practice, and more or less Traces of teaching objectives to a certain extent deviated from the "curriculum requirements". Classroom observation shows that students who sit in the back of the class who are not serious lectures are in the back four words or are doing four simulation exercises. During the interview, the teacher mentioned that students attached great importance to the final exam and the quaternary examination. Near the end of the period, there are always some students to remind the teacher as soon as possible finished textbook content, leaving time to explain the examination questions and scope. Especially in the second grade, college English teachers generally will compress the teaching content of teaching materials, increase the contents of the four exercises. Although college English teachers agree that English learning is not intended to pass the exam, but to improve the comprehensive application of language ability, but they will, without exception, will cater to the wishes of students in the classroom teaching content to make helpless compromise. College English teachers must really change their ideas and understand the relationship between testing and teaching. In the daily teaching, teachers should consciously guide students to dilute the role of the examination, to strengthen the training of students to listen to the ability to stimulate students 'ability to self-learning, so that English teaching can really guide and promote the growth of students' ability, ideological innovation The It is true that the phenomenon of examination-oriented education is also related to the imperfect management of education system, the lack of scientific examination and evaluation system. Therefore, the school and education management departments still need to vigorously reform the evaluation mechanism, and actively guide teachers and students to cultivate English application ability, the full implementation of quality education.

Lifelong learning to promote teacher knowledge constantly updated, thinking with the times. It has a certain stage of the teacher's career, if the lack of learning, teaching level and professional development will be stagnant. Self - learning is the driving force and source of teacher's growth. During the interview, the teachers were asked to gain continuous professional development through training, academic education, research activities and so on, and the content of the study focused on theoretical study and scientific research methods. Combined with the results of classroom observation, whether it is slightly jerky teacher role change, the difference between the larger activities of the classroom organization, or uneven teaching ability, and teachers have the theoretical knowledge and the degree of closely related. Therefore, the theoretical knowledge of college English teachers teaching concept of the formation and teaching behavior has a positive value, the 
desire for theoretical knowledge is from the needs of college English teachers.

\section{Reflections on the Professional Development of College English Major}

The professional development of teachers is influenced by many external factors, but in the final analysis is internal, self. If a teacher does not have a strong self-development needs, no matter how good the external environment and security conditions are of no avail. In this sense, self development is the fundamental way to realize the professional development of college English teachers. The professional development of teachers is based on its autonomy, active pursuit of self-development on the basis of. This requires college English teacher teachers according to the needs of the new teaching model to adjust their own knowledge structure and teaching skills, according to the needs of students to adjust the teaching content and teaching focus. Teachers to actively reflect on the teaching activities, in the process of constantly sum up experience to improve and improve themselves; to strengthen the language theory and language teaching theory of learning, and constantly enrich their theoretical knowledge, teaching guidance, and promote their professional development.

In the era of information technology, teachers rely solely on the power of individuals seeking professional development is far from enough. Teachers are often uneven inside the teacher, in the isolated teaching state, due to the lack of communication between teachers, the individual gap will be more and more. College English teachers in the teaching content, model and evaluation and so has a lot in common, teacher cooperation has a particularly important value. A tacit understanding team is equivalent to providing a platform for teachers to learn from each other, learn from each other, and communicate with each other. It is important to realize teachers' common development in cooperation and interaction. The professional development of college English teachers requires a variety of teacher training as a guarantee. Teacher training in the education administrative departments, teaching units, publishers, various societies and other organizations and support to regular, long-term to carry on. The training of college English teachers mainly includes three aspects: basic training of language skills; language teaching theory training; language teaching practical training.

Under the new teaching model, both the novice teachers and the experienced teachers, their teaching methods are deeply influenced by the long-term traditional teaching methods. How to break through the previous teaching model for the development of teachers at this stage is very important. Teaching and training to help teachers learn from each other, learn from each other, but if the rise to the height of vocational training, the need for education departments or schools to do a careful and meticulous planning, for example, the school regularly held teaching contest, teaching observation; To teach to carry out a more thorough school to observe the brothers and universities taught teachers; send English teachers to visit the school and so on. In addition, the Shanghai Foreign Language Education Publishing House held a national college English teacher teaching contest in the past two years. It was a great opportunity for college English teachers to provide a good opportunity for college English teachers to participate in short-term training and to teach the award-winning teachers.

Language teachers are very critical of language proficiency. The language they use in the classroom plays an important role for the students and their voice intonation, grammar and pragmatics are all students imitate the sample. Therefore, college English teachers must strive to listen, speak, read, write, translation and other aspects of continuous improvement of their professional level, so that they have solid basic skills of language. At present, some domestic colleges and universities have launched a foreign language teacher training program, such as overseas short-term training, graduate courses and other classes. These training have greatly improved the teacher's language level. Theoretical guidance is an indispensable factor in the professional development of college English teachers. The lack of theoretical guidance will affect teachers' deep understanding of teaching reform, the analysis of teaching materials, the handling of teaching content and the ability to carry out research and writing papers. Through the training of effective modern educational theory, college English teachers can obtain the frontier knowledge of 
the subject, understand the theoretical basis behind the concept of teaching reform, grasp the theoretical methods involved in teaching practice, solve the specific problems encountered in teaching practice, lead the reflection and teaching connotation To the essence of the upgrade. The practical approach to theoretical training mainly includes academic seminars, short-term training courses and expert lectures and other forms.

\section{Conclusion}

This paper analyzes the necessity of professional development of college English teachers in the new situation by analyzing the realistic background of professional development of college English teachers. Then, through the investigation and analysis of the status quo of professional development of college English teachers under the new teaching mode, this paper puts forward the suggestions to promote the development of college English teachers Effective Ways. The author believes that this study will provide ideas for the reform of college English teaching in colleges and universities, provide guidance for the growth and development of college English teachers, and provide some basis for teachers' training in education management.

\section{References}

[1] Lu Jing. Study on foreign language teacher's professional development model based on micro-curriculum [J].Research on Curriculum Education, 2015 (27)

[2] Tan Meiyun. Reflection practice and business English teacher professional development model [J].Journal of Hubei University of Economics, 2015 (12)

[3] Zheng Wen, Li Yangxiu. Evaluation of professional development model of lifelong teachers in American universities [J].Education Development Research, 2006 (18)

[4] Liu Jianxin, Sun Zhenxiang. Construction of teachers' professional development model based on resource development and utilization [J].Contemporary Education Forum, 2006 (17)

[5] Zhou Yan. College teachers professional development model [J]. Journal of Shangqiu Teachers College, 2008 (04)

[6] Zhang Tong, Ma Yunpeng. The connotation, characteristics and implementation strategy of "three" teachers professional development model [J]. Modern Education Management, 2016 (06) 